\title{
Greenhouse gas emissions from a horizontal subsurface-flow constructed wetland for wastewater treatment in small villages
}

\author{
Taşeli B.K. \\ Giresun University, Faculty of Engineering, Environmental Engineering Department, 28200 Giresun, Turkey \\ Received: 30/05/2018, Accepted: 15/06/2020, Available online: 16/06/2020 \\ *to whom all correspondence should be addressed: e-mail: basak.taseli@giresun.edu.tr \\ https://doi.org/10.30955/gnj.002782
}

\section{Graphical abstract}

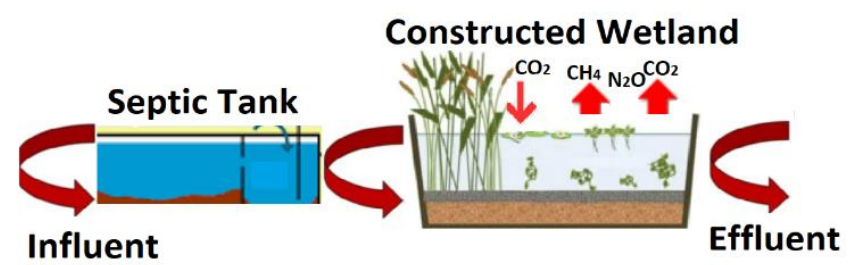

\begin{abstract}
Constructed wetlands with a land-intensive, low energy and less operational requirement have been used as a sustainable green technology for treating wastewaters. But are constructed wetlands sustainable? The objectives of the present study are to evaluate one year monitored horizontal subsurface-flow constructed wetland's treatment efficiency from May 2017 to May 2018 and to estimate the greenhouse gas emissions (GHG) in terms of $\mathrm{N}_{2} \mathrm{O}$ and $\mathrm{CH}_{4}$. As field data show the average removal efficiencies are low but are all within the effluent standard for water quality. One year average of high suspended solids (91.1\%), high total nitrogen (\%85.6), low total phosphorous (22.4\% TP), low organic matter $\left(43.1 \% \mathrm{BOD}_{5}\right.$ \& $35.9 \%$ COD) removals are obtained. One year average methane and nitrous oxide emissions at the outlet of constructed wetland are calculated as 17.52 and $0.29 \mathrm{~kg} / \mathrm{d}$, respectively.
\end{abstract}

Keywords: Horizontal subsurface-flow constructed wetland, greenhouse gas emission, wastewater treatment, sustainability.

\section{Introduction}

Constructed wetlands designed and constructed to mimic natural wetland systems for removing contaminants are basically composed of vegetation, substrates, soils, microorganisms and water, utilize complex processes involving physical, chemical, and biological mechanisms (e.g., sedimentation, filtration, precipitation, volatilization, adsorption, plant uptake, and various microbial processes) (Vymazal, 2011).

Flow and environmental dispersion are essential to ecological risk assessment and ecological restoration associated with wetlands. It is argued that wind on contaminant dispersion in a wetland flow dominated by free-surface effect. It is shown that the length and duration of influenced region can change greatly under wind (Zeng et al., 2012; Jiang et al., 2019).

While the treatment performance of CWs is critically dependent on the optimal operating parameters (water depth, hydraulic retention time and load, feeding mode and design of setups, etc.) which could result in variations in removal efficiency of contaminants, plant species and media types are crucial influencing factors for the treatment in CWs as they are considered to be the main biological component of CWs. Macrophytes frequently used in CW treatments include emergent plants, submerged plants, floating leaved plants and free-floating plants. In reality, more than 150 macrophyte species have been used in CWs however only a limited number of these plant species are very often planted. The most common used emergent species reported are Phragmites spp., Typha spp., Scirpus spp., Iris spp., Juncus spp. and Eleocharis spp. (Vymazal, 2011).

Chen et al. (2014) stated that in rural areas wastewater treatment technologies like activated sludge and membrane methods are not feasible enough for widespread application. Constructed wetlands (CWs) however are attracting great concern due to lower cost, easy operation and less maintenance requirements as a reasonable option for treating wastewater in rural areas. CWs can be grouped into 2 categories namely free-water surface and subsurface-flow which is further divided to horizontal subsurface-flow and vertical subsurface-flow. Chen et al. (2008) stated that vertical sub-surface flow CW is more effective due to provide better water distribution and more oxygen content. Zhou et al. (2009) compared the horizontal subsurface constructed wetland with conventional wastewater treatment systems based on emergy analysis. CWs are found to be less energy- 
intensive, less cost in construction, operation and maintenance compared to conventional activated sludge system. It is also implied that CWs with less investment in construction materials are suitable for the small towns or villages where land prices are cheaper while in the urban areas conventional biological treatment system is more popular due to the high land prices and highly polluted wastewaters.

Chen et al. (2008) compared removal efficiency of the vertical sub-surface $\mathrm{CW}$ with some horizontal subsurfaceflow CW. BOD $5, C O D$ and TSS removal efficiencies of the pilot $\mathrm{CW}$ are found to be the same, while the removal efficiencies of TP and $\mathrm{NH}_{3}-\mathrm{N}$ are better compared to those of the other CW systems.

Are constructed wetlands sustainable? Dixon et al. (2003) reported that constructed wetlands have less global warming potential ( $\mathrm{CO}_{2}$ emissions) and less energy use than conventional treatment. Machado et al. (2007) found that wetlands also reduced aquatic toxicity and eutrophication compared to conventional activated sludge wastewater treatment. A sustainable solution means minimized costs, minimized energy use, minimized land area required, minimized loss of nutrients, minimized waste production, maximized products like clean water, biogas, biomass, fertilizers, compost, and maximized qualitative sustainability indicators like social acceptance, institutional requirements, etc. But it is not always possible to design a wastewater treatment that minimizes cost, energy use and land area, while maximizing performance.

Maltais et al. (2009) measured greenhouse gas emissions of $3 \mathrm{mg} / \mathrm{m}^{2} / \mathrm{d} \mathrm{N}_{2} \mathrm{O}, 1400 \mathrm{mg} / \mathrm{m}^{2} / \mathrm{d} \mathrm{CO}_{2}$ and $5 \mathrm{mg} / \mathrm{m}^{2} / \mathrm{d} \mathrm{CH}_{4}$ in horizontal flow constructed wetland (HFCW). Moreover, Sovik et al. (2006) stated that vertical flow constructed wetlands (VFCWs) have significantly higher areal gaseous emissions than HFCWs, and gas emissions were correlated to temperature, substrate supply (influent $\mathrm{N}$ and $\mathrm{C}$ concentrations), and degree of oxidation in the wetland. The quantity and impact of $\mathrm{CH}_{4}$ and $\mathrm{N}_{2} \mathrm{O}$ are important because it is reported that $\mathrm{CH}_{4}$ has 25 times and $\mathrm{N}_{2} \mathrm{O}$ has 298 times the global warming potential of $\mathrm{CO}_{2}$ (IPPC, 2006).

Teiter and Mander (2005) measured $\mathrm{CO}_{2}, \mathrm{CH}_{4}, \mathrm{~N}_{2}$, and $\mathrm{N}_{2} \mathrm{O}$ fluxes in both horizontal and vertical subsurface-flow constructed wetlands in Estonia and reported that the global influence of constructed wetlands is not significant, i.e., even if all global domestic wastewater were treated by constructed wetlands, the emitted GHG would be less than $1 \%$ of total anthropogenic emissions. They also reported the averaged experimental data of $788.33 \mathrm{mg} \mathrm{CO} 2 / \mathrm{m}^{2} \mathrm{~h}, 4$ $\mathrm{mg} \mathrm{CH} / \mathrm{m}^{2} \mathrm{~h}$ and $0.79 \mathrm{mg} \mathrm{N} 2 \mathrm{O} / \mathrm{m}^{2} \mathrm{~h}$.

Presented in this paper is a pilot-scale horizontal subsurface-flow constructed wetland's treatment efficiency from May 2017 to May 2018 at two monitoring sites, one located in the inlet and one in the outlet of constructed wetland. Estimation of the greenhouse gas emissions (GHG) in terms of $\mathrm{N}_{2} \mathrm{O}$ and $\mathrm{CH}_{4}$ is a specific objective of the study. Although many ecological evaluations have been conducted on the wastewater treatment mode, the GHG emissions of these plants are neglected. This study presents GHG emissions from wetlands by calculating of $\mathrm{N}_{2} \mathrm{O}$ and $\mathrm{CH}_{4}$.

\section{Materials and methods}

\subsection{Pilot-scale horizontal subsurface-flow constructed wetland system (HSSF CW's)}

Constructed wetlands as well as other natural remediation systems are cheaper, less energy and chemical dependent, less mud producing, no specialist staff required systems. The most important processes that occur in wetlands are sedimentation, biological breakdown by bacteria growing aerobic and anaerobic conditions within gravel surface and plant roots. TSS (total suspended solids) removal is mainly based on physical methods like sedimentation and filtration. In horizontal subsurface-flow constructed wetlands, wastewater is discharged horizontally from the system and there is no contact with the flow and surface.

Pilot-scale horizontal subsurface-flow constructed wetland system consists of one pond and one septic tank made of steel-reinforced concrete designed for pretreatment of solids by settling and allowing for conversion of organic nitrogen to ammonium. Pilot-scale constructed wetland represented in Figure 1 is designed treating domestic wastewater of 500 people with hydraulic retention time of $35 \mathrm{~L} / \mathrm{m}^{2}$.day.

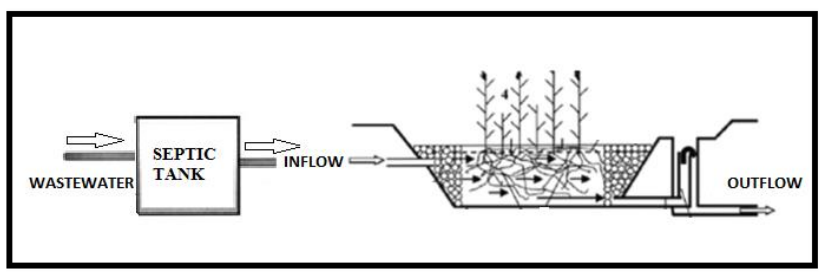

Figure 1. Current constructed wetland system

\subsection{Transplanting of Phragmites sp.}

Natural and washed gravel 2-12 $\mathrm{mm}$ in diameter and $50 \mathrm{~cm}$ in height is covered with soil and young plants of reed (Phragmites australis) are planted as 4 roots per square meters with $15 \mathrm{~cm}$ length rhizome and stem collected from surrounding natural marshes are transplanted on the same day. After sowing, each bed is flooded with fresh water to about $15 \mathrm{~cm}$ above the course gravel and the plants are allowed to establish themselves in fresh water. Two months later raw wastewater replaced the fresh water as an influent to the wetland.

\subsection{Chemical analysis}

Pilot-scale CW's efficiency is monitored monthly by measuring BOD (biochemical oxygen demand), COD (chemical oxygen demand), SS (suspended solids), TN (total nitrogen), TP (total phosphorous), TC (total coliform) and FC (fecal coliform) according to standard methods presented in Table 1. 


\subsection{Emission calculating principles}

Methods deriving from 2006 IPCC Guidelines for National Greenhouse Gas Inventories are used for the emission calculations in the study (IPCC, 2006).

\subsubsection{Methane $\left(\mathrm{CH}_{4}\right)$}

The direct methane emissions are the function of the amount of degradable carbon in the wastewater and sludge, and an emission factor. The emission factor (EF) is a function of the maximum $\mathrm{CH}_{4}$ producing potential $\left(\mathrm{B}_{0}\right)$ and the methane correction factor (MCF) for the wastewater treatment and discharge system. The $\mathrm{B}_{\circ}$ is the maximum amount of $\mathrm{CH}_{4}$ that can be produced from a given quantity of organics in the wastewater. (IPPC, 2014) recommends the $\mathrm{B}_{0}$ value to be $0.6 \mathrm{~kg} \mathrm{CH}_{4} / \mathrm{kg}$ BOD removal and the uncertainty range to be $\pm 30 \%$. The MCF indicates that the extent to which the $\mathrm{CH} 4$ producing capacity $\left(\mathrm{B}_{0}\right)$ is realized in each type of treatment and discharge pathway and system. The $\mathrm{CH}_{4}$ emissions from constructed wetlands and $\mathrm{CH}_{4}$ emission factors for constructed wetlands are given in Equation 1 and 2, respectively.

Table 1. Standard methods, equipments and method of measurement used in analysis

\begin{tabular}{clcc}
\hline Parameter & Equipment & Standard method & Method of measurement \\
\hline TP & DRLANGE-XION500 & TS ISO 8466-1:1997 & Spectrophotometric \\
\hline TN & DRLANGE-XION500 & TS ISO 8466-1:1997 & Spectrophotometric \\
\hline COD & DRLANGE-XION500 & TS2789 ISO 6060:2000 & Spectrophotometric \\
\hline BOD & HACH- BODTrak ${ }^{\text {TM } I I}$ & APHA, AWWA, WEF & Respirometric \\
\hline SS & TS 7094 EN 872:1999 & Membrane Filtration \\
\hline TC & SARTORIUS vacuum filter & TSEN ISO 9308-1:2004 & Membrane Filtration \\
\hline FC & SARTORIUS vacuum filter & TSEN ISO 9308-1:2004 & Membrane Filtration
\end{tabular}

ISO International Organization for Standardization

$\mathrm{CH}_{4}$ Emissions from Constructed Wetlands

$$
\mathrm{CH}_{4} \text { emissions }=\sum_{\mathrm{j}}\left(\mathrm{TOW}_{\mathrm{j}} \cdot \mathrm{EF}_{\mathrm{j}}\right)+\sum_{\mathrm{i}, \mathrm{j}}\left(\mathrm{TOW}_{\mathrm{ij}} \cdot \mathrm{EF}_{\mathrm{j}}\right)
$$

Where; $\mathrm{CH}_{4}$ emissions $=\mathrm{CH}_{4}$ emissions in inventory year, $\mathrm{kg}$ $\mathrm{CH}_{4} / \mathrm{yr}$, $\mathrm{TOW}_{\mathrm{j}}=$ total organics in wastewater entering $\mathrm{CW}$ in inventory year, $\mathrm{kg} \mathrm{BOD} / \mathrm{yr}$ or $\mathrm{kg} \mathrm{COD/yr}, \mathrm{EF}_{\mathrm{j}}=$ emission factor, $\mathrm{kg} \mathrm{CH} 4 / \mathrm{kg} \mathrm{BOD}$ (for domestic wastewater only) or $\mathrm{kg} \mathrm{CH} 4 / \mathrm{kg}$ COD (for domestic and industrial wastewater), If more than one type of $\mathrm{CW}$ is used in an industrial sector this factor would need to be a TOW $\mathrm{W}_{\mathrm{ij}}$ weighted average, $\mathrm{i}=$ industrial sector, $\mathrm{j}=$ type of $\mathrm{CW}$

$\mathrm{CH}_{4}$ Emission factor for Constructed Wetlands

$$
\mathrm{EF}_{\mathrm{j}}=\mathrm{B}_{0} \cdot \mathrm{MCF}_{\mathrm{j}}
$$

Where; $\mathrm{EF}_{\mathrm{j}}=$ emission factor, $\mathrm{kg} \mathrm{CH} / \mathrm{kg} \mathrm{BOD,} \mathrm{kg} \mathrm{CH}_{4} / \mathrm{kg}$ $\mathrm{COD}, \mathrm{j}=$ type of $\mathrm{CWs}, \mathrm{B}_{0}=$ maximum $\mathrm{CH}_{4}$ producing capacity, $\mathrm{kg} \mathrm{CH}_{4} / \mathrm{kg} \mathrm{BOD}$ or $\mathrm{kg} \mathrm{CH}_{4} / \mathrm{kg}$ COD, $\mathrm{MCF}_{\mathrm{j}}=$ methane correction factor (fraction).

\subsubsection{Nitrous oxide $\left(\mathrm{N}_{2} \mathrm{O}\right)$}

Nitrous oxide is associated with the microbial conversion of nitrogen compound in the wastewater. It occurs as emissions from treatment plants or from wastewater after disposal of effluent into waterways, lakes or the sea. Typically, emissions from advanced centralized wastewater treatment plants are much smaller than those from no treatment effluent. The emission factor (0.005) is taken for domestic wastewater nitrogen effluent, referring to the default value recommended by (IPCC, 2014). The factor $44 / 28$ is the conversion of $\mathrm{kg} \mathrm{N}_{2} \mathrm{O}-\mathrm{N}$ into $\mathrm{kg} \mathrm{N}_{2} \mathrm{O}$. A simplified equation is given in equation 3 .

$\mathrm{N}_{2} \mathrm{O}$ Emissions from Constructed Wetlands

$$
\mathrm{N}_{2} \mathrm{O}=\sum_{\mathrm{j}}\left(\mathrm{N}_{\mathrm{j}} \cdot E \mathrm{~F}_{\mathrm{j}} \cdot 44 / 28\right)+\sum_{\mathrm{i}, \mathrm{j}}\left(\mathrm{N}_{\mathrm{i}, \mathrm{j}} \cdot E \mathrm{~F}_{\mathrm{j}} \cdot 44 / 28\right)
$$

Where; $\mathrm{N}_{2} \mathrm{O}=\mathrm{N}_{2} \mathrm{O}$ emissions in inventory year, $\mathrm{kg} \mathrm{N} \mathrm{N}_{2} \mathrm{O} / \mathrm{yr}$, $\mathrm{N}_{\mathrm{j}}$ = total nitrogen in domestic wastewater entering CWs in the inventory year, $\mathrm{kgN} / \mathrm{yr}, \mathrm{N}_{\mathrm{i}, \mathrm{j}}=$ total nitrogen in industrial wastewater entering $\mathrm{CWs}$ in the inventory year, $\mathrm{kgN} / \mathrm{yr}, \mathrm{EF}_{\mathrm{j}}$ = emission factor, $\mathrm{kgN}_{2} \mathrm{O}-\mathrm{N} / \mathrm{kg} \mathrm{N}$, If more than one type of $\mathrm{CW}$ is used in an industrial sector this factor would need to be a $N_{i, j}$ weighted average, $i=$ industrial sector, $\mathrm{j}=$ type of cW.

\section{Results and discussion}

3.1. Wastewater treatment efficacy of pilot-scale horizontal sub surface flow constructed wetland system

Removal efficiency are examined in terms of, suspended solids (SS), total nitrogen (TN), total phosphate (TP), chemical oxygen demand (COD) concentrations, biochemical oxygen demand (BOD) and number of total coliforms and fecal coliforms. The parameters in question are measured at inlet and outlet of CW (Figure 1).

HSSF constructed wetlands are commonly used for secondary treatment of municipal wastewater. It is reported that oxygen transport capacity in these systems is insufficient to ensure aerobic decomposition thus anaerobic process play an important role in HSSF CW'S (IPCC, 2006).

Nutrients like N, P uptaken by reed plants are recycled within reed beds since there are no harvest practices. Eq. (3) is used to estimate $\mathrm{N}_{2} \mathrm{O}$ emission from HSSF CW. Sludge accumulated in the septic tank is cleaned up regularly by vacuum pump and is fed into sludge dry beds every two months. A half amount of the total BOD removal, i.e. 6.1 $\mathrm{kg}$, is assumed to be either anaerobically degraded in the septic tank or transported to sludge drying beds. I am assuming the system's MCF would be between 0.1 (the value for regular cleaned up latrine) and 0.5 (the value for septic tank). Thus, a mean MCF value of 0.3 is taken for the calculations. 
Table 2 gives the removal efficiencies of the one year operated constructed wetland between May 2017 and May 2018. As can be seen in Table 2, no significant removal of the measured parameters of BOD, COD and TP were obtained. The highest values obtained for SS and TN.

Table 2. Percentage removal of organics, nutrients, suspended solids and pathogens

\begin{tabular}{cccccccc}
\hline \multirow{2}{*}{ Parameter } & \multicolumn{3}{c}{ Wetland inlet (mg/L) } & \multicolumn{4}{c}{ Wetland outlet (mg/L) } \\
\cline { 2 - 9 } & Max. & Min. & Avg. & Max. & Min. & Avg. & \% Removal (Avg.) \\
\hline BOD $_{5}$ & 87.6 & 14 & 31.3 & 40 & 4 & 17.8 & 43.1 \\
\hline COD & 303.8 & 44.2 & 124 & 167 & 40 & 79.5 & 35.9 \\
\hline SS & 182 & 10 & 56.03 & 6.8 & 2 & 4.98 & 91.1 \\
\hline TN & 10.1 & 8.85 & 10 & 1.73 & 1.1 & 1.43 & 85.6 \\
\hline TP & 1.98 & 0.2 & 1.03 & 2.6 & 0.1 & 0.83 & 22.4 \\
\hline TC & $450 \times 10^{3}$ & $25 \times 10^{3}$ & $121 \times 10^{3}$ & $212 \times 10^{3}$ & $50 \times 10^{3}$ & $51 \times 10^{3}$ & 57.9 \\
\hline FC & $220 \times 10^{3}$ & $30 \times 10^{3}$ & $76 \times 10^{3}$ & $106 \times 10^{3}$ & $15 \times 10^{3}$ & $23 \times 10^{3}$ & 69.7 \\
\hline
\end{tabular}

The study of the CWs system performance included the evaluation of the treated waters quality in comparison to the Turkish effluent water quality standards. The average values obtained in the effluent for $\mathrm{COD}$ and $\mathrm{BOD}_{5}$ were in agreement with the limits of the Turkish directives. There is no effluent quality standard for TN, TP, TC and FC for domestic wastewater treatment plant serving for 84-2000 person set in TWPCR (2004).
Moderate removal efficiencies were obtained for TC and FC.

Table 3. Horizontal subsurface constructed wetland's GHG emissions

\begin{tabular}{ccc}
\hline \multirow{2}{*}{ Parameter $(\mathbf{k g} / \mathbf{d})$} & \multicolumn{2}{c}{ (May 2017-May 2018) } \\
\cline { 2 - 3 } & Inlet & Outlet \\
\hline $\mathrm{BOD}$ & 514 & 292 \\
\hline $\mathrm{TN}$ & 165 & 23 \\
\hline $\mathrm{CH}_{4}$ emission & 30.84 & 17.52 \\
\hline $\mathrm{N}_{2} \mathrm{O}$ emission & 2.05 & 0.29 \\
\hline
\end{tabular}

\subsection{Collection system}

Sewage pipe is a free flow system without pumping. Underground pipes are closed so it is not assumed to be a source of $\mathrm{CH}_{4}$ emission (IPCC, 2006). There is no pumping installed between septic tank and HSSF CW and no electricity is used in the system.

\section{Conclusions}

The pilot-scale Horizontal Subsurface-flow CWs performance complied with the Turkish treated wastewater quality standards as $50 \mathrm{mg} / \mathrm{l}, 180 \mathrm{mg} / \mathrm{l}$ and 70 $\mathrm{mg} / \mathrm{I}$ for $\mathrm{BOD}_{5}, \mathrm{COD}$ and $\mathrm{SS}$, respectively. Unfortunately, there is no effluent quality standard for TN, TP, TC and FC for domestic wastewater treatment plant serving for 84-2000 person set in TWPCR (2004). As field data show the average removal efficiencies were low but were all within the effluent standard for water quality. The author suggested that one year average of low organic matter (43.1\% $\mathrm{BOD}_{5} \& 35.9 \% \mathrm{COD}$ ) removals could be related to oxygen deficient areas occurring in the root-zone system. To provide better water distribution and more oxygen content, vertical subsurface-flow model can be adopted.

High suspended solids (91.1\%) removal shows that the root network reduces water velocities and promotes settling and filtration. High total nitrogen (85.6\%) removal shows nitrification and denitrification depending on different dissolved oxygen concentration worked well.

\subsection{Estimated pilot-scale HSSF constructed wetland} greenhouse gas emissions

Table 3 shows calculated BOD and TN load and GHG emissions using Equation 1, 2 and 3 in terms of $\mathrm{CH}_{4}$ and $\mathrm{N}_{2} \mathrm{O}$. One-year average methane and nitrous oxide emissions at the outlet of constructed wetland are calculated as 17.52 and $0.29 \mathrm{~kg} / \mathrm{d}$, respectively.

On the other hand low total phosphorous reoval (22.4\%) shows poor cations in HSFCW since phosphorous removed mainly by cation exchange reactions. Natural materials rich in iron and calcium cations could be added to CW to increase removal efficiency as Chen et al. (2008) suggested. The low removal is believed to the fact that wastewater flows over the sediment and dissolved nutrients could not penetrate through diffusion.

Low TP removal can also be due to the accumulation of plant growth, organic matter in bottom sediments which decreases dissolved oxygen and redox potential of the sediment and releases $P$ to the water column. Moreover, clogged pores due to excess suspended solids and excess sludge production from the microorganisms cannot be aerated as it would be necessary for wastewater treatment with nitrification.

Another reason could be a poor establishment of Phragmites australis (reed) in the wetland which is also discussed by Tanner C.C. (1996).

Another objective of the present study is to estimate the greenhouse gas emissions (GHG) in terms of $\mathrm{N}_{2} \mathrm{O}$ and $\mathrm{CH}_{4}$ of horizontal subsurface-flow constructed wetland. Oneyear average methane and nitrous oxide emissions at the outlet of constructed wetland were calculated as 17.52 and $0.29 \mathrm{~kg} / \mathrm{d}$, respectively. Methane and nitrous oxide emissions are in accordance with literature given in IPCC 
(2014) implying less global warming potential and less energy use than conventional treatment. $\mathrm{CO}_{2}$ emissions are not included in greenhouse gas emissions since $\mathrm{CO}_{2}$ from wastewater is considered biogenic and the Phragmites australis significantly decreases overall $\mathrm{CO}_{2}$ emissions by carbon uptake.

\section{Acknowledgements}

This research work is a part of the project, which is supported by Giresun University FEN-BAP-A-160317-42. The author thanks the Giresun University for financial support of this work.

\section{References}

Chen Y., Wen Y., Zhou Q. and Vymazal J. (2014), Effects of plant biomass on denitrifying genes in subsurface-flow constructed wetlands, Bioresource Technology, 157, 341-345.

Chen Z.M., Chen B., Zhou J.B., Li Z., Zhou Y., Xi X.R., Lin C. and Chen G.Q. (2008), A vertical subsurface-flow constructed wetland in Beijing, Communication in Nonlinear Science and Numerical Simulation, 13, 1986-1997.

Dixon A., Simon M. and Burkitt T. (2003), Assessing the environmental impact of two options for small-scale wastewater treatment: comparing a reedbed and an aerated biological filter using a life cycle approach, Ecological Engineering, 20, 297-308.

IPCC (2014), 2013 Supplement to the 2006 IPCC Guidelines for national greenhouse gas inventories: Wetlands, Hiraishi T., Krug T., Tanabe K., Srivastava N., Baasansuren J., Fukuda M. and Troxler T.G. (eds), Published: IPCC, Switzerland.

IPCC (2006), Guidelines for national greenhouse gas inventories, In: Eggleston H.S., Buendia L., Miwa K., Ngara T. and Tanabe K. (eds), The National Greenhouse Gas Inventories Programme, The Intergovernmental Panel on Climate Change, Hayama, Kanagawa, Japan.

Jiang W.Q. and Chen G.Q. (2019), Environmental dispersion in layered wetland: Moment based asymptotic analysis, Journal of Hydrology, 569, 252-264.

Machado A.P., Urbano L., Brito A.G., Janknecht P., Salas J.J. and Nogueira R. (2007), Life cycle assessment of wastewater treatment options for small and decentralized communities: energy-saving systems versus activated sludge, Water Science and Technology, 56(3), 15-22.

Maltais-Landry G., Maranger R. and Brisson J. (2009), Effect of artificial aeration and macrophyte species on nitrogen cycling and gas flux in constructed wetlands, Ecological Engineering, 35, 221-229.

Sovik A.K., Augustin J., Heikkinen K., Huttunen J.K., Necki J.M., Karjalainen S.M., Klove B., Liikanen A., Mander U. and Puustinen,M. (2006), Nitrous oxide and methane from constructed wetlands in Europe, Journal of Environmental Quality, 35, 2360-2373.

Tanner C.C. (1996), Plants for constructed wetland treatment systems. A comparison of the growth and nutrient uptake of eight emergent species, Ecological Engineering, 7, 59-83.

Teiter and Mander (2005), Emission of $\mathrm{N}_{2} \mathrm{O}, \mathrm{N}_{2}, \mathrm{CH}_{4}$, and $\mathrm{CO}_{2}$ from constructed wetlands for wastewater treatment and from riparian buffer zones, Ecological Engineering, 25(5), 528-541.

TWPCR (2004), Water Pollution Control Regulation (in Turkish), prepared by Ministry of Environment and Forest, Official Journal, 25(687), 18-76.
Vymazal J. (2011), Plants used in constructed wetlands with horizontal subsurface-flow: a review, Hydrobiologia, 674, 133-156.

Zeng L., Wu Y.H., Ji P., Chen B., Zhao Y.J., Chen G.Q. and Wu Z. (2012), Effect of wind on contaminant dispersion in a wetland flow dominated by free-surface effect, Ecological Modelling, 237-238, 101-108.

Zhou J.B., Jiang M.M., Chen B. and Chen G.Q. (2009), Emergy evaluations for constructed wetland and conventional wastewater treatments, Communication in Nonlinear Science and Numerical Simulation, 14, 1781-1789. 